(ISSN Cetak 1978-6573) (ISSN Online 2477-300X)

\title{
PENGARUH EARNING PER SHARE (EPS), RETURN ON EQUITY (ROE) DAN DEBT TO EQUITY RATIO (DER) TERHADAP RETURN SAHAM DENGAN KEBIJAKAN DIVIDEN SEBAGAI VARIABEL INTERVENING PADA PERUSAHAAN INDUSTRI BARANG KONSUMSI YANG TERDAFTAR DI BEI
}

\author{
Arum Narwita Sari ${ }^{1}$, Sri Hermuningsih ${ }^{2}$ \\ Universitas Sarjanawiyata Tamansiswa Yogyakarta \\ arumnarwitasari@gmail.com¹ ${ }^{1}$ hermun_feust@yahoo.co.id ${ }^{2}$
}

\begin{abstract}
ABSTRAK
Penelitian ini bertujuan untuk mengetahui pengaruh Earning per Share (EPS), Return on Equity (ROE) dan Debt to Equity Ratio (DER) terhadap return saham dengan kebijakan dividen sebagai variabel intervening di perusahaan industri barang konsumsi yang terdaftar di Bursa Efek Indonesia pada periode 2014-2018. Data yang digunakan adalah data panel dengan rincian data time series yaitu 5 tahun dan data cross section sebanyak 20 perusahaan. Data-data yang diperoleh selanjutnya diolah dengan menggunakan teknik analisis data yaitu regresi linier berganda yang didukung dengan uji asumsi klasik yaitu uji normalitas, uji multikoliniearitas, uji heteroskdastisitas dan uji autokorelasi. Dalam penelitian ini juga menggunakan uji sobel. Berdasarkan hasil analisis data menunjukkan bahwa: (1) EPS memiliki pengaruh positif dan signifikan terhadap DPR, hal ini ditunjukkan dengan nilai 0.002 dan probabilitas 0.000. (2) ROE memiliki pengaruh negative dan tidak signifikan terhadap DPR hal ini ditunjukkan dengan nilai -0.009 dan probabilitas 0.781. (3) DER memiliki pengaruh positif dan signifikan terhadap DPR hal ini ditunjukkan dengan nilai 3.087 dan probabilitas 0.030. (4) DPR memiliki pengaruh negatif tidak signifikan terhadap return saham hal ini ditunjukkan oleh nilai -0.004 dan probabilitas 0.377. (5) EPS memiliki pengaruh negatif tidak signifikan terhadap return saham hal ini ditunjukkan oleh nilai 1.931E-6 dan probabilitas 0.867. (6) ROE memiliki pengaruh negatif terhadap return saham hal ini ditunjukkan oleh nilai -8.957E-7 dan probabilitas 0.999. (7) DER memiliki pengaruh positif tidak signifikan terhadap return saham hal ini ditunjukkan oleh nilai 0.046 dan probabilitas 0.244 dan (8) DPR tidak memediasi variabel EPS, ROE dan DER terhadap return saham yang hal ini ditunjukkan dengan nilai z-hitung lebih kecil dari nilai z-tabel $(-5<1.96 \mathrm{EPS}),(0.1270<1.96 \mathrm{ROE})$ dan $(-6.7234<$ 1.96DER). Berdasarkan hasil tersebut dapat disimpulkan bahwa kebijakan dividen (DPR) tidak mampu menjadi variabel intervening dari variabel EPS, ROE, dan DER terhadap return saham pada perusahaan sektor industri barang konsumsi yang terdaftar di BEI periode 2014-2018. Hal ini dibuktikan berdasarkan penelitian uji sobel.
\end{abstract}

Kata kunci: Earning per Share, Return on Equity, Debt to Equity Ratio, Kebijakan Dividen, Return Saham

\footnotetext{
ABSTRACT

This study aims to examine the effect of Earning per Share (EPS), Return on Equity Ratio (ROE) and Debt to Equity Ratio (DER) on stock returns with dividend policy as an intervening variable in consumer goods industry companies listed on the Indonesia Stock Exchange for the period 2014-2018. Data used is the panel data with the detail of 5 years time series and 20 companies of cross section data. The data obtained further processed by using the data analysis techniques is multiple linear regression supported by classical assumption test, namely the test of normality, multikoliniearity test, heteroskdastisity test and autocorrelation test. In this study also used Sobel test. Based on the results of data analysis shows that: (1) EPS has a positive and significant influence on the DPR which is indicated by 0.002 value and 0.000 for probability. (2) The ROE has a negative and insignificant influence on the DPR which is indicated by the -0.009 and probability of 0781 . (3) DER has a positive and significant influence on the DPR which is indicated by the value of 3.087 and the probability of 0.030 . (4) The
} 
DPR has insignificant negative influence on the stock return this is demonstrated by value -0.004 and probability of 0.377 . (5) EPS has an insignificant negative influence on the stock return which is demonstrated by values $1.931 \mathrm{E}-6$ and probability 0.867 . (6) ROE has a negative influence on the stock return which is demonstrated by values $8.957 \mathrm{E}-7$ and probability 0.999 . (7) DER has an insignificant positive influence on the stock return which is demonstrated by the value of 0.046 and the probability of 0.244 and (8) DPR does not mediate the EPS, ROE and DER variables on stock return, this is indicated by the calculated $\mathrm{z}$ value is smaller than the $\mathrm{z}$ table value $(-5<1.96),(0.1270<1.96)$ and $(-$ $6.7234<1.96$ ). Dividend Policy (DPR) is not able to be an intervening variable of the EPS, ROE and DER variables on Saham Returns in the Consumer Goods Industry sector companies listed on the Indonesia Stock Exchange in the 2014-2018 period. This is proven bythe research of the Sobel test.

Keywords: Earning per Share, Return on Equity, Debt to Equity Ratio, Dividend Policy, Stock Return

\section{PENDAHULUAN}

Pasar modal saat ini mengalami perkembangan sangat pesat dan memegang peranan penting dalam memobilisasi dana dari masyarakat yang ingin berinvestasi di pasar modal. Investasi merupakan salah satu cara yang dapat dilakukan untuk mendapatkan sejumlah keuntungan dengan cara menanamkan modal atau membeli asset berharga berharga yang ditawarkan di pasar modal, ada banyak pilihan dalam melakukan investasi. Salah satu investasi menarik adalah dengan cara membeli atau menjual saham. Sesuai prinsip investasi yaitu "low risk, low return" yang berarti bahwa semakin tinggi risiko maka akan semakin tinggi return yang diperoleh, begitupun sebaliknya. Investasi saham dikenal dengan mangandung risiko tinggi, namun mempunyai return yang tinggi pula. Hal ini dikarenakan terjadi fluktuasi harga saham yang tidak pasti. Dalam investasi saham terdapat dua macam return, yaitu berupa dividend dan capital gains.

Dividen merupakan laba perusahaan yang dibagkan kepada investor setiap periode tertentu. Namun tidak semua perusahaan akan membagikan dividen, karena beberapa perusahaan yang menahan dividen untuk ditanamkan kembali sebagai modal. Sedangkan capital gains adalah keuntungan dari selisih penjualan atau pembelian saham yang didapatkan dari kelebihan nilai jual saham terhadap nilai beli saham tersebut. Sedangkan risiko yang timbul dari investasi saham yaitu capital loss dan likuidasi. Selain dividen sebagai keuntungan dividen juga bisa menjadi suatu risiko karena tidak semua perusahaan membagikan dividen kepada investornya, sehingga para investor hanya akan mengandalkan keuntungan dari capital gain. Capital loss adalah kebalikan dari capital gain yaitu suatu keadaan dimana seorang investor akan menanggung kerugian akibat nilai jual saham lebih rendah dari nilai beli. Sedangkan risiko likiudasi adalah keadaan dimana perusahaan mengalami kebangkrutan.

Rasio keuangan membantu dalam mengidentifikasi faktor-faktor yang dapat mempengaruhi harga saham. Rasio keuangan yang digunakan untuk memprediksi return saham dalam penelitian diantaranya Earning per Share (EPS), Return on Equity (ROE) dan Debt to Equity Ratio (DER). Earning per Share (EPS) menggambarkan profitabilitas perusahaan pada setiap lembar saham. Return on Equity (ROE) merupakan salah satu rasio yang dapat digunakan untuk mengukur kemampuan perusahaan dalam menghasilkan laba bersih berdasarkan modal tertentu. Sedangkan Debt to Equity Ratio (DER) merupakan rasio yang sering digunakan untuk menilai utang dengan ekuitas. Beberapa penelitian yang berkaitan dengan faktor-faktor yang 
mempengaruhi Return Saham antara lain penelitian yang dilakukan oleh (Nurhayani \& Mandala, 2016) membuktikan bahwa EPS dan DER memiliki hubungan positif terhadap Return Saham, pada penelitian (Safitri, Okky \& Sinarwati, 2015) menunjukkan bahwa ROE berpengaruh dan signifikan terhadap return saham.

\section{A. Earning Per Share (EPS)}

Earning per Share (EPS) adalah rasio yang menunjukkan bagian laba untuk setiap saham. EPS menggambarkan profitabilitas perusahaan yang tergambar pada setiap lembar saham. Rumus untuk menghitung EPS suatu perusahaan adalah sebagai berikut (Darmadji, 2012):

$E P S=\frac{\text { Laba Bersih Setelah Pajak }}{\text { Jumlah Saham Beredar }}$

\section{B. Return on Equity (ROE)}

Return on Equity (ROE) adalah salah satu rasio yang dapat digunakan untuk mengukur kemampuan perusahaan dalam menghasilkan laba bersih berdasar modal tertentu. Perhitungan ROE menggunakan rumus sebagai berikut (Mohamad, 2015):

$$
R O E=\frac{\text { Laba Bersih Setelah Pajak }}{\text { Ekuitas }} \times 100 \%
$$

\section{Debt to Equity Ratio (DER)} Debt to Equity Ratio (DER) merupakan rasio yang digunakan untuk menilai utang dengan ekuitas. Pengukuran DER dapat dihitung menggunakan rumus sebagai berikut (Aryani \& Rita, 2016):

DER $=\frac{\text { Total Hutang }}{\text { Total Ekuitas }} \times 100 \%$

\section{Kebijakan Dividen}

Kebijakan Dividen (DPR) adalah dividen per lembar saham dibagikan dengan laba per lembar saham. Rasio ini dapat digunakan untuk menghitung perbandingan antara laba per lembar saham yang diperoleh perusahaan dengan laba yang dibagikan sebagai dividen (Hermuningsih, 2012). Perhitungan rumus Kebijakan Dividen sebagai berikut:

$$
D P R=\frac{\text { Dividen per lembar saham }}{\text { Laba per lembar saham }}
$$

\section{E. Return Saham}

Return saham merupakan pendapatan saham dan perubahan nilai harga saham periode $\mathrm{t}$ dengan $\mathrm{t}-1$ dan berarti bahwa semakin tinggi perubahan harga saham makan semakin tinggi return saham yang dihasilkan. Perhitungan rumus Return Saham sebagai berikut (Hartono, 2014):

$$
R_{t}=\frac{P_{t}-P_{t-1}}{P_{t-1}} \times 100 \%
$$

Keterangan:

$R_{t}=$ Return Saham

$P_{t}=$ Harga saham saat ini

$P_{t-1}=$ Harga saham periode sebelumnya 




Gambar 1. Kerangka Pemikiran

\section{METODE PENELITIAN}

\section{A. Sifat Penelitian}

Penelitian ini menggunakan pendekatan kuantitatif karena data yang digunakan berbentuk angka pada analisis statistiknya, sedangkan eksplansinya penelitian ini termasuk penelitian asosiatif (hubungan).

\section{B. Definisi Operasional}

1. Variabel Dependen

Return saham merupakan pendapatan saham dan perubahan nilai harga saham periode $t$ dengan t-1 dan berarti bahwa semakin tinggi perubahan harga saham maka semakin tinggi return saham yang dihasilkan. Perhitungan rumus return saham sebagai berikut (Hartono, 2014)

$$
R_{t}=\frac{P_{t}-P_{t-1}}{P_{t-1}} \times 100 \%
$$

Keterangan:

$R_{t}=$ Return Saham

$P_{t}=$ Harga saham saat ini

$P_{t-1}=$ Harga saham periode sebelumnya

2. Variabel Independen
a. Earning per Share (EPS) adalah rasio yang menunjukkan bagian laba

untuk setiap saham. EPS menggambarkan profitabilitas menggembirakan pemegang saham, karena semakin besar laba yang disediakan untuk pemegang saham kemungkinan peningkatan jumlah dividen yang diterima pemegang saham. Perhitungan rumus EPS sebagai berikut:

$E P S=\frac{\text { Laba bersih setelah pajak }}{\text { Jumlah saham beredar }}$

b. Return on Equity (ROE) adalah perbandingan antara laba usaha terhadap ekuitas. Satu hal yang perlu diperhatikan adalah penggunaan laba bersih sebagai ukuran. Karena jika terdapat jumlah yang besar pada pos "non operating income (expenses)", hal itu sangat mempengaruhi rasio ini. Perhitungan rumus ROE sebagai berikut (Mohamad, 2015):

$R O E=\frac{\text { Laba bersih }}{\text { Total ekuitas }} \times 100 \%$

c. Debt to Equity Ratio (DER) merupakan rasio yang digunakan untuk menilai utang dengan ekuitas. Rasio 
ini menyatakan bahwa semakin tinggi rasio ini, berarti modal sendiri semakin sedikit dibandingkan dengan hutangnya. DER dirumuskan sebagai berikut (Aryani \& Rita, 2016) :

$$
\text { DER }=\frac{\text { Total hutang }}{\text { Total ekuitas }} \times 100 \%
$$

3. Variabel Intervening Kebijakan Dividen (DPR) digunakan untuk menghitung perbandingan antara laba per lembar saham yang diperoleh perusahaan dengan laba yang dibagikan sebagai dividen (Hermuningsih, 2012). Rumus untuk menghitung DPR sebagai berikut:

$$
D P R=\frac{\text { Dividen per lembar saham }}{\text { Laba per lembar saham }}
$$

\section{Populasi dan Sampel}

Penelitian ini menggunakan data sekunder. Populasi dalam penelitian ini adalah perusahaan sektor Industri Barang Konsumsi yang terdaftar di BEI pada periode 20142018, dan sampel penelitian ini menggunakan teknik purposive sampling.

\section{Teknik Analisis Data}

Teknik analisis data yang digunakan untuk menganalisis data adalah analisis linear berganda. Analisis linear berganda digunakan untuk melihat pengaruh variabel.

\section{HASIL DAN PEMBAHASAN}

\section{A. Uji Asumsi Klasik}

Sebelum dilakukannya pengujian hipotesis terlebih dahulu dilakukan pengujian asumsi klasik, agar hasil dari penelitian ini valid dan tidak menyebabkan hasil yang bias.
1. Uji Normalitas

Berdasarkan hasil pengujian EPS, ROE dan DER terhadap DPR menunjukkan hasil signifikan 0.050 diatas tingkat signifikansi 5\%. Pengujian EPS, ROE, DER dan DPR terhadap Return saham menunjukkan hasil 0.331 diatas tingkat signifikansi 5\%.

2. Uji Multikoliniearitas

Berdasarkan hasil pengujian EPS terhadap DPR menunjukkan hasil tolerance 0.979 dan VIF 1.021, ROE terhadap DPR menunjukkan hasil tolerance 0.975 dan VIF 1.025, DER terhadap DPR menunjukkan hasil tolerance 0.965 dan VIF 1.036. Pengujian EPS terhadap Return Saham menunjukkan hasil tolerance 0.637 dan VIF 1.569, ROE terhadap Return Saham menunjukkan hasil tolerance 0.974 dan VIF 1.027, DER terhadap Return Saham menunjukkan hasil tolerance 0.870 dan VIF 1.149, DPR terhadap Return Saham menunjukkan hasil tolerance 0.621 dan VIF 1.611. Berdasarkan hasil tersebut disimpulkan bahwa tidak terjadi Multikoliearitas.

3. Uji Heteroskedastisitas

Berdasarkan hasil pengujian EPS, ROE dan DER terhadap DPR menunjukkan hasil signifikan $0.705,0.960$ dan 0.319 diatas tingkat signifkansi 5\%, maka dapat disimpulkan tidak terjadi Heteroskedastisitas. Pengujian EPS, ROE, DER dan DPR terhadap Return Saham menunjukkan hasil signifikan $0.841,0.493,0.637$ dan 0.451 diatas tingkat signifikansi $5 \%$. Berdasarkan hasil tersebut 
disimpulkan bahwa tidak terjadi Heteroskedastisitas.

4. Uji Autokorelasi

Berdasarkan hasil pengujian EPS, ROE dan DER terhadap DPR menunjukkan hasil 0.775 diatas signifikansi 5\%, maka dapat disimpulkan bahwa tidak terjadi Autokorelasi.

Pengujian EPS, ROE, DER dan DPR terhadap Return Saham menunjukkan hasil 0.253 diatas signifikansi 5\%, maka dapat disimpulkan bahwa tidak terjadi Autokorelasi.

5. Hasil Analisis Regresi Linear Berganda menggunakan Uji-t.

Berdasarkan hasil Uji-t diperoleh hasil sebagai berikut:

Tabel 1. Hasil Uji-t Dividend Payout Ratio

\begin{tabular}{llll}
\hline \multicolumn{4}{l}{ Coefficients $^{\mathrm{a}}$} \\
\hline Model & & & \\
& $\mathrm{B}$ & $\mathrm{t}$ & Sig. \\
\hline 1 & -.237 & -.149 & .883 \\
(Constant) & & & \\
EPS & .002 & 4.968 & .000 \\
ROE & -.009 & -.280 & .781 \\
DER & 3.087 & 2.238 & .030 \\
\hline
\end{tabular}

Sumber: Diolah Peneliti (2019)

Berdasarkan hasil olah data variabel EPS diperoleh t-hitung sebesar 0.002 dengan probabilitas sebesar 0.000 lebih kecil dari taraf signifikansi 0.05 , hal ini berarti EPS berpengaruh positif signifikan terhadap variabel DPR. Variabel ROE diperoleh t-hitung sebesar 0.009 dengan probabolitas sebesar 0.781 lebih besar dari taraf signifikan 0.05 , hal ini berarti ROE berpengaruh negative tidak signifikan terhadap DPR. Variabel DER diperoleh t-hitung sebesar 3.087 dengan probabilitas sebesar 0.030 lebih kecil dari taraf signifikansi 0.050 , hal ini berarti DER berpengaruh positif dan signifikan terhadap DPR.
Tabel 2. Hasil Uji-t Return Saham

\begin{tabular}{|c|c|c|c|}
\hline \multicolumn{4}{|c|}{ Coefficients $^{\mathrm{a}}$} \\
\hline Model & & & \\
\hline & B & $\mathrm{t}$ & Sig. \\
\hline $\begin{array}{l}1 \\
\text { (Constant) }\end{array}$ & .212 & 4.928 & .000 \\
\hline EPS & $\begin{array}{r}-1.931 \mathrm{E}- \\
6\end{array}$ & -.168 & .867 \\
\hline ROE & $\begin{array}{r}-8.957 \mathrm{E}- \\
7\end{array}$ & -.001 & .999 \\
\hline DER & .046 & 1.182 & .244 \\
\hline DPR & -.004 & -.892 & .377 \\
\hline
\end{tabular}

Sumber: Diolah Peneliti (2019)

Berdasarkan hasil olah data variabel EPS diperoleh t-hitung sebesar 1.931E-6 dengan probabilitas sebesar 0.867 lebih besar dari taraf signifikansi 0.05, hal ini berarti EPS berpengaruh negative tidak signifikan terhadap Return Saham. Variabel ROE diperoleh t-hitung sebesar -8.957E-7 dengan probabilitas sebesar 0.999 lebih besar dari taraf signifikan 0.05, hal ini berarti ROE berpengaruh negative tidak signifikan terhadap Return Saham. Varaibel DER diperoleh t-hitung sebsar 0.046 dengan probabilitas 0.244 lebih besar dari taraf signifikansi 0.05 , hal ini berarti DER berpengaruh positif tidak signifikan terhadap Return Saham. Variabel DPR diperoleh t-hitung sebesar -0.004 dengan probabilitas 0.377 lebih besar dari taraf signifikansi 0.05 , hal ini berarti DPR berpengruh negative tidak signifikan terhadap Return Saham.

Berdasarkan hasil perhitungan uji sobel test kemampuan DPR sebagai variabel intervening Earning per Share (EPS) terhadap Return Saham diperoleh nilai hitung sebesar $-5<$ nilai signifikansi 1.96, variabel Return on Equity (ROE) terhadap Return Saham diperoleh nilai hitung sebesar $0.1270<$ nilai signifikansi 1.96 dan variabel Debt to Equity Ratio (DER) terhadap Return Saham diperoleh nilai hitung sebesar $-6.7234<$ nilai signifikansi 1.96. Hasil tersebut menunjukkan bahwa pengaruh EPS, 
ROE, DER melalui Kebijakan Dividen (DPR) tidak signifikan, sehingga dapat disimpulkan bahwa Kebijakan Dividen (DPR) tidak terbukti memediasi EPS, ROE dan DER terhadap Return Saham.

\section{B. Pembahasan}

1. Pengaruh Earning per Share (EPS) terhadap Kebijakan Dividen (DPR)

Dari perhitungan uji secara parsial antara EPS terhadap DPR diperoleh nilai sebesar 0.002 dan nilai signifikansi sebesar 0.000 . Karena nilai signifikansi EPS terhadap DPR lebih kecil dari 5\%. Dalam penelitian ini menunjukkan bahwa EPS berpengaruh positif signifikan terhadap DPR sehingga hipotesis diterima.

2. Pengaruh Return on Equity (ROE) terhadap Kebijakan Dividen (DPR)

Dari perhitugan uji secara parsial antara ROE terhadap DPR diperoleh nilai sebesar -0.009 dan nilai signifikansi sebesar 0.781 . Karena nilai signifikansi ROE terhadap DPR lebih besar dari 5\%. Dalam penelitian ini menunjukkan bahwa ROE berpengaruh negative tidak signifikan terhadap DPR sehingga hipotesis ditolak.

3. Pengaruh Debt to Equity Ratio (DER) terhadap Kebijakan Dividen (DPR)

Dari perhitungan uji secara parsial antara DER terhadap DPR diperoleh nilai sebesar 3.087 dan nilai sinifikansi sebesar 0.030 . Karena nilai signifikansi lebih kecil dari 5\%. Dalam penelitian ini menunjukkan bahwa DER berpengaruh positif signifikan terhadap DPR sehingga hipotesis diterima.
4. Pengaruh Kebijakan Dividen (DPR) terhadap Return Saham Dari perhitungan uji secara parsial antara DPR terhadap Return Saham diperoleh nilai sebesar 0.004 dan nilai signifikansi sebesar 0.377. Karena nilai signifikansi lebih besar dari 5\%. Dalam penelitian ini menunjukkan bahwa DPR berpengaruh negative tidak signifkan terhadap Return Saham.

5. Pengaruh Earning per Share (EPS) terhadap Return Saham Dari perhitungan uji secara parsial antara EPS terhadap Return Saham diperoleh nilai sebesar 1.931E-6 dan nilai signifikansi sebesar 0.867. Karena nilai signifikansi lebih besar dari 5\%. Dalam penelitian ini menunjukkan bahwa EPS berpengaruh negative tidak signifikan terhadap Return Saham.

6. Pengaruh Return on Equity (ROE) terhadap Return Saham

Dari perhitungan uji secara parsial antara ROE terhadap Return Saham diperoleh nilai sebesar 8.957E-7 dan nilai signifikansi sebesar 0.999. Karena nilai signifikansi lebih besar dari 5\%. Dalam penelitian ini menunjukkan bahwa ROE berpengaruh negative tidak signifikan terhadap Return Saham.

7. Pengaruh Debt to Equity Ratio (DER) terhadap Return Saham Dari perhitungan uji secara parsial antara DER terhadap Return Saham diperoleh nilia sebesar 0.046 dan nilai signifikansi sebesar 0.244. Karena nilai signifikansi lebih besar dari 5\%. Dalam penelitian ini menunjukkan bahwa DER berpengaruh positif 
tidak signifikan terhadap Return Saham.

\section{KESIMPULAN DAN SARAN}

A. Kesimpulan

Berdasarkan hasil penelitian yang telah dilakukan dengan melakukan tahap pengumpulan dan pengolahan data, maka pada penelitian mengenai Pengaruh Earning per Share (EPS), Return on Equity (ROE) dan Debt to Equity Ratio (DER) terhadap Return Saham dengan Kebijakan Dividen (DPR) sebagai variabel intervening, dapat ditarik kesimpulan sebagai berikut:

1. Earning per Share (EPS) berpengaruh positif signifikan tarhadap Kebijakan Dividen (DPR) maka hipotesis diterima.

2. Return on Equity (ROE) berpengaruh negative tidak signifikan terhadap Kebijakan Dividen (DPR) maka hipotesis ditolak.

3. Debt to Equity Ratio (DER) berpengaruh positif signifikan terhadap Kebijakan Dividen (DPR) maka hipotesis diterima.

4. Kebijakan Dividen (DPR) berpengaruh negative tidak signifikan terhadap Return Saham, maka hipotesis ditolak.

5. Earning per Share (EPS) berpengaruh negative tidak signifikan terhadap Return Saham, maka hipotesis ditolak.

6. Return on Equity (ROE) berpengaruh negative tidak signifikan terhadap Return Saham, maka hipotesis ditolak.

7. Debt to Equity Ratio (DER) berpengaruh negative tidak signifikan terhadap Return Saham, maka hipotesis ditolak.

8. Berdasarkan hasil sobel test, Kebijakan Dividen (DPR) tidak terbukti menjadi variabel intervening untuk EPS, ROE dan DER terhadap Return Saham.

\section{B. Keterbatasan Penelitian}

Sampel yang digunakan merupakan sampel kecil dari seluruh perusahaan yang terdaftar di BEI. Pengambilan sampel menggunakan teknik purposive sampling pada perusahaan Industri Barang Konsumsi. Kurun waktu periode untuk penelitian ini relative sngkat yaitu tahun 2014-2018.

\section{Saran}

Berdasarkan hasil penelitian ini, penulis memberikan beberapa saran. Bagi perusahaan harus meningkatkan lagi dalam hal efisiensi dan efektivitas dengan memanfaatkan berbagai faktor-faktor yang mendukung usaha perusahaan. Bagi peneliti selanjutnya sebaiknya menggunakan variabel lain yang dapat mempengaruhi Kebijakan Dividend dan Return Saham.

\section{DAFTAR PUSTAKA}

Aryani, L., Andini, R., \& Santoso, E.B. (2016). Pengaruh EPS, CR, DER dan PBV terhadap Harga Saham dengan Kebijakan Dividen sebagai Variabel Intervening. Jurnal Ilmiah Mahasiswa S1 Akuntansi Universitas Pandanaran, 4(4).

Darmadji, F. (2012). Pengaruh EPS, CR, DER dan PBV terhadap Harga Saham dengan Kebijakan Dividen sebagai Variabel Intervening.

Hartono. (2014). Pengaruh Profitabilitas, Leverage, Likuiditas dan Ukuran Perusahaan terhadap Return Saham Perusahaan Farmasi di BEI. E-Jurnal Manajemen Unud, 5(11).

Hermuningsih, S. (2012). Pengantar Pasar Modal.

Mohamad, S. (2015). Pasar Modal dan Manajemen Portofolio. 
DERIVATIF: Jurnal Manajemen

Vol. 14 No. 1 April 2020

(ISSN Cetak 1978-6573) (ISSN Online 2477-300X)

Nurhayani Aisah, A., \& Mandala, K. (2016). Pengaruh Return on Equity, Earning Per Share, Firm Size dan Operating Cash Flow terhadap Return Saham. E-Jurnal Manajemen Unud, 5(11), 6907-6936.

Safitri, Okky., \& Sinarwati, A.T.A. (2015). Analisis Pengaruh Profitabilitas, Likuiditas dan Leverage terhadap Return Saham. E-Journal Sl Ak Universitas Pendidikan Ganesha Jurusan Akuntansi S1, 3. 